\title{
SUPLEMENTASI PROBIOTIK Saccharomyces spp.Kb-13 DALAM RANSUM TERHADAP PRODUKSI, KARAKTERISTIK KUALITAS TELUR, DAN KOLESTEROL KUNING TELUR AYAM LOHMANN BROWN
}

\author{
BIDURA, I G. N. G. \\ Fakultas Peternakan, Universitas Udayana, Denpasar-Bali, Indonesia \\ E-mail: bidura_unud@yahoo.com
}

\begin{abstract}
ABSTRAK
Penelitian ini dilakukan untuk menentukan efek dosis Saccharomyces spp.Kb-13 (isolasi dari cairan rumen kerbau) sebagai probiotik pada kinerja produksi, karakteristik kualitas telur, dan kadar kolesterol kuning telur ayam Lohmann Brown. Seratus dua puluh ayam petelur Lohmann Brown umur 72 minggu digunakan dalam percobaan rancangan acak lengkap (RAL) dengan 4 macam perlakuan, yaitu: So: tanpa pemberian probiotik; S1: Dengan penggunaan 0,10\% Saccharomyces spp.Kb-13; S2: dengan penggunaan 0,20\% Saccharomyces spp.Kb-13; and S3: dengan penggunaan 0,30\% Saccharomyces spp.Kb-13. Hasil penelitian menunjukkan bahwa pemberian Saccharomyces spp.Kb-13 secara nyata $(\mathrm{P}<0,05)$ dapat meningkatkan berat telur total, efisiensi penggunaan pakan, warna kuning telur, persentase kuning dan kulit telur, dan ketebalan cangkang. Suplementasi probiotik ke dalam diets ternyata tidak berpengaruh nyata $(\mathrm{P}>0,05)$ terhadap konsumsi ransum, indek telur, $\mathrm{HU}$, dan $\mathrm{BJ}$ telur. Administrasi 0,20-0,30\% Saccharomyces spp.Kb-13 menghasilkan kadar kolesterol kuning yang lebih rendah $(\mathrm{P}<0,05)$. Disimpulkan bahwa penerapan dalam diet 0,20-0,30\% Saccharomyces spp.Kb-13 meningkatkan massa telur, efisiensi pakan, warna kuning telur, persentase kuning telur dan kulit telur, dan ketebalan cangkang telur, serta menurunkan kadar kolesterol dalam yolk pada ayam petelur Lohmann Brown
\end{abstract}

Kata kunci: probiotik, ketebalan cangkang, kolesterol, ayam

\section{SUPPLEMENTATION OF PROBIOTICS Saccharomyces spp.KB-13 IN DIETS ON EGG PRODUCTIONS, EGG CHARACTERISTICS, AND YOLK CHOLESTEROL IN EGG OF LOHMANN BROWN LAYING HENS}

\begin{abstract}
This study was conducted to determine the effect of Saccharomyces spp. KB-13 dose (isolated from buffalo rumen fluid) as a probiotic on egg production performance, egg quality characteristics, and yolk cholesterol levels in Lohmann Brown laying hens. One hundred and twenty 72-week Lohmann Brown laying hens were used in a complete randomized design (CRD) experiment with 4 treatments, namely: So: without probiotics; S1: with the use of $0.10 \%$ Saccharomyces spp. KB-13; S2: with the use of 0.20\% Saccharomyces spp. KB-13; and S3: with the use of 0.30\% Saccharomyces spp. KB-13, respectively. The results showed that administration of Saccharomyces spp.Kb-13 significantly $(\mathrm{P}<0.05)$ were increased total egg weight, feed efficiency, egg yolk color, percentage of yolk and eggshell, and shell thickness. The addition of probiotics into diets apparently did not have a significant effect $(\mathrm{P}>0.05)$ on the feed consumption, egg index, HU, and BJ of eggs. Administration 0.20-0.30\% Saccharomyces spp.Kb-13 decreased yolk cholesterol levels $(\mathrm{P}<0.05)$. It was concluded that the application in the diet 0,20-0,30\% Saccharomyces spp. KB-13 increased egg mass, feed efficiency, egg yolk color, egg yolk and eggshell percentage, and eggshell thickness, and reduced cholesterol levels in yolk in Lohmann Brown laying hens.
\end{abstract}

Key words: probiotics, shell thickness, cholesterol, chicken 


\section{PENDAHULUAN}

Telur diakui sebagai sumber protein, lemak, vitamin, dan zat makanan berharga lainnya yang sempurna, akan tetapi telur juga mengandung kadar kolesterol tinggi, yang sangat terkait dengan penyakit kardiovaskular pada manusia (Bidura et al., 2019). Oleh karena itu, penelitian untuk mengurangi kandungan kolesterol dalam telur tidak hanya membantu meningkatkan upaya kesehatan masyarakat, tetapi juga dapat bermanfaat bagi industri telur. Beberapa hasil penelitian penggunaan strain probiotik dalam ransum (Abdelqader et al., 2013; Lei et al., 2013; Khan dan Naz, 2013), ternyata mampu menekan konsentrasi kolesterol kuning telur dan meningkatkan kualitas telur.

Penggunaan probiotik dalam industri unggas menjadi menarik diaplikasikan, karena meningkatnya kekhawatiran tentang resistensi bakteri terhadap antibiotik, serta teresidunya antibiotik dalam produk ternak (Tang et al., 2018). Probiotik, telah terbukti menjadi alternatif yang paling disukai dan efektif untuk pengganti antibiotic growth promotor (AGP). Penelitian pendahuluan menunjukkan bahwa ragi Saccharomyces spp. terutama digunakan sebagai agensia probiotik pada ayam pedaging dan ayam petelur nyata dapat meningkatkan performa produksi ayam (Bidura et al., 2012; Bidura et al., 2016; Hasan et al., 2016; Siti et al., 2014), meningkatkan kualitas gizi pakan (Bidura et al., 2014; Bidura et al., 2015; Bidura dan Siti 2017; Candrawati et al., 2014), menekan jumlah lemak perut dan kadar kolesterol dalam serum bebek dan ayam pedaging (Puspani et al., 2016; Bidura et al., 2016; Ristiani et al., 2017), serta kadar kolesterol telur pada ayam dan itik petelur (Bidura et al., 2019).

Penelitian sebelumnya telah mengisolasi ragi Saccharomyces spp.Kb-13 dari rumen kerbau. Isolat ini memiliki aktivitas enzim (CMC-ase) dan telah lolos tes sebagai agen probiotik (telah lulus uji suhu, $\mathrm{pH}$, asam dan garam empedu, dan mampu melakukan dekonjugasi asam empedu), dan memiliki kemampuan untuk mendegradasi serat kasar dari pakan (Bidura dan Siti, 2017). Penerapan probiotik dalam diet broiler telah meningkatkan kinerja pertumbuhan dan efisiensi pakan, serta menurunkan kadar kolesterol serum dan daging pada itik jantan (Bidura et al., 2019), Isolat Saccharomyces spp. dapat meningkatkan protein kasar dan energi yang dapat dimetabolisme dari dedak padi. (Bidura dan Siti, 2017). Fathi et al. (2018) melaporkan bahwa suplementasi probiotik tidak meningkatkan kinerja produksi telur, akan tetapi dapat meningkatkan kualitas kulit telur. Dilaporkan oleh Istiqomah et al. (2018) bahwa Saccharomyces cerevisiae berpotensi untuk mengasimilasi kolesterol in vitro.

Ragi probiotik seperti Saccharomyces spp. juga telah terbukti merangsang sistem kekebalan tubuh anak ayam tanpa menurunkan kinerja pertumbuhan (Bai et al., 2013). Oleh karena itu, penelitian ini bertujuan untuk mengevaluasi pengaruh tingkat penggunaan probiotik Saccharomyces spp.Kb-13 (isolasi dari cairan rumen kerbau) terhadap performa produksi, karakteristik kualitas telur, dan kolestrol kuning telur ayam Lohman Brown.

\section{MATERI DAN METODE}

\section{Ternak dan Rancangan Percobaan}

Seratus dua puluh ekor ayam Lohmann Brown yang sedang bertelur umur 72 minggu digunakan dalam percobaan rancangan acak lengkap (RAL). Semua ayam yang digunakan mempunyai berat badan homogen $(1780,52 \pm 28,36 \mathrm{~g})$ dan umur peneluran yang sama. Semua ransum perlakuan adalah iso-energi dan isoprotein. Ransum diformulasi sesuai kebutuhan ayam petelur (Scott et al., 1982) selama 8 minggu percobaan. Bahan pakan dan komposisi kimia dari pakan ditunjukkan pada Tabel 1

Table 1. Komposisi bahan pakan dan zat makanan dalam ransum ayam petelur Lohmann Brown umur 72-80 minggu

\begin{tabular}{|c|c|c|c|c|c|}
\hline \multirow{2}{*}{\multicolumn{2}{|c|}{ Komposisi (\%) }} & \multicolumn{4}{|c|}{ Perlakuan } \\
\hline & & so & S1 & S2 & S3 \\
\hline Jagung kuning & & 60.01 & 60.01 & 60.00 & 59.05 \\
\hline Dedak padi & & 17.19 & 17.09 & 17.00 & 17.85 \\
\hline Kacang kedelai & & 9.37 & 9.37 & 9.37 & 9.36 \\
\hline Tepung ikan & & 9.03 & 9.03 & 9.02 & 9.02 \\
\hline Mineral-B12*) & & 4.41 & 4.41 & 4.41 & 4.42 \\
\hline Saccharomyces spp.Kb-13 & & 0.00 & 0.10 & 0.20 & 0.30 \\
\hline Total & & 100 & 100 & 100 & 100 \\
\hline \multicolumn{6}{|l|}{ Komposisi zat makanan $* *)$ : } \\
\hline Energi termetabolis & (kcal/kg) & 2901 & 2900 & 2899 & 2899 \\
\hline Protein kasar & $(\%)$ & 16.02 & 16.01 & 16.00 & 15.98 \\
\hline Serat kasar & $(\%)$ & 3.91 & 3.91 & 3.91 & 3.98 \\
\hline Lemak kasar & $(\%)$ & 7.13 & 7.13 & 7.13 & 7.18 \\
\hline Calsium & (\%) & 3.91 & 3.91 & 3.91 & 3.91 \\
\hline P-available & $(\%)$ & 1.11 & 1.11 & 1.11 & 1.11 \\
\hline Lysin & (\%) & 1.06 & 1.06 & 1.06 & 1.06 \\
\hline Metionin+sistein & $(\%)$ & 0.68 & 0.68 & 0.68 & 0.68 \\
\hline Triptofan & (\%) & 0.21 & 0.21 & 0.21 & 0.21 \\
\hline
\end{tabular}

*) Komposisi Mineral-B12 per $10 \mathrm{~kg}$ : Calsium: 49\%; Phosphor 14\%; Iron: $40000 \mathrm{mg}$ Manganese: $27500 \mathrm{mg}$; Mg: $27.500 \mathrm{mg}$; Zinccum: $25 \mathrm{mg}$; Vit-B12: $4.50 \mathrm{mg}$ and Vit D3: 500000 IU. PT. Eka Farma. Deptan RI No. D 8109127 FTS

**) Berdasarkan perhitungan Scott et al. (I982)

Ayam petelur secara acak dibagi menjadi empat perlakuan, yaitu: So: tanpa pemberian probiotik; S1: dengan pemberian 0,10\% Saccharomyces spp. KB-13; S2: dengan pemberian 0,20\% Saccharomyces spp. KB13; dan $\mathrm{S}_{3}$ : dengan pemberian 0,30\% Saccharomyces spp. KB-13. Setiap perlakuan terdiri dari enam ulangan dengan lima ekor ayam yang secara acak ditempatkan 
ke dalam masing-masing petak kandang dengan ukuran $100 \times 70 \times 45 \mathrm{~cm}$ (panjang $\times$ lebar $\times$ tinggi). Setiap ransum percobaan dalam bentuk mash dan ayam perlakuan memiliki akses bebas untuk pakan dan air minum selama percobaan.

\section{Probiotik}

Probiotik yang digunakan dalam penelitian ini adalah Saccharomyces spp. $K B-13$, yang diisolasi dari cairan rumen kerbau yang potong di RPH. Isolat telah lolos tes dan telah dianggap potensial sebagai probiotik berdasarkan penelitian kami sebelumnya (Bidura dan Siti 2017). Isolat Saccharomyces spp. KB-13 sebagai probiotik disiapkan di Laboratorium Kimia Nutrisi Makanan ternak di Fakultas Peternakan, Universitas Udayana. Setiap $1 \mathrm{~g}$ kultur mengandung setidaknya 5,9×10 6 CFU Saccharomyces spp.

\section{Prosedur Penelitian}

Kandang diberi lampu penerangan pada malam hari, demikian juga halnya dengan pakan dan air minum selalu tersedia sepanjang hari. Semua ayam ditimbang pada saat dimulainya penelitian (umur ayam 72 minggu) dan diakhir penelitian (umur 80 minggu). Telur dikumpulkan setiap hari dan produksi telur dinyatakan berdasarkan hens day produksi (\%). Jumlah dan berat telur pada masing-masing petak kandang (unit percobaan) dicatat kemudian digunakan untuk menghitung berat telur rata-rata untuk semua unit percobaan. Total massa/berat telur dihitung dengan mengalikan berat telur dengan produksi telur. Konsumsi ransum diukur setiap minggu. Konsumsi ransum harian per ekor dihitung berdasarkan asupan total pakan selama seminggu pada masing-masing petak kandang (unit percobaan) selama periode percobaan. Rasio konversi pakan (kg pakan/kg telur) pada masingmasing unit percobaan dihitung setiap minggu selama periode percobaan. Parameter kualitas telur diukur dengan menggunakan alat multi-tester telur.

\section{Kualitas telur dan kuning telur.}

Pemeriksaan kualitas telur dan kulit telur (berat cangkang, ketebalan cangkang telur, bobot kuning telur, kulit dan albumin, warna kuning telur) dilakukan pada akhir percobaan. Untuk tujuan ini, lima telur diambil antara pukul 08.00 dan 12.00 secara acak dari setiap unit percobaan pada minggu ke delapan (akhir percobaan). Telur ditimbang secara individual dipecah di atas alas kaca. Intensitas warna kuning telur dievaluasi dan direkam sesuai dengan Roche Yolk Color fans. Berat albumen dihitung dengan mengurangi bobot kuning telur dan cangkang dari masing-masing berat telur. Untuk mengukur berat cangkang, kulit telur dibersihkan dari setiap albumen yang menempel lalu membran dihilangkan; kulit telur kemudian dikeringkan pada suhu kamar dan dinyatakan sebagai persentase dari seluruh telur. Kadar kolesterol kuning telur dihitung dan dinyatakan dalam miligram/gram kuning telur.

\section{Analisis statistik}

Semua data dianalisis dengan ANOVA untuk menentukan perbedaan antara perlakuan pada selang kepercayaan $5 \%(\mathrm{P}<0,05)$. Jika perbedaan ditemukan, maka analisis lebih lanjut dilakukan dengan uji rentang ganda Duncan.

\section{HASIL DAN PEMBAHASAN}

Hasil penelitian menunjukkan bahwa suplementasi probiotik Saccharomyces spp. KB-13 sebanyak 0,10$0,30 \%$ ke dalam ransum ternyata tidak berpengaruh nyata $(\mathrm{P}>0,05)$ terhadap berat badan awal, berat badan akhir, konsumsi ransum, dan produksi telur ayam (Tabel 2). Grup ayam yang mendapat suplementasi 0,20-0,30\% probiotik Saccharomyces spp. KB-13 mempunyai berat telur total dan rasio konversi pakan (pakan Konsumsi: berat telur), yang nyata $(\mathrm{P}<0,05)$ lebih tinggi daripada grup ayam kontrol (So). Berat telur total pada ayam kontrol adalah 375.66 g/ekor/ minggu (Tabel 2). Berat telur pada Grup ayam S2 dan S3, masing-masing adalah: $4,66 \%$ dan $4,74 \%$ nyata $(\mathrm{P}<0,05)$ lebih tinggi daripada kontrol. Rataan nilai feed conversion ratio (konsumsi pakan: berat telur) pada Grup ayam yang diberi probiotik (perlakuan S2 dan $\left.\mathrm{S}_{3}\right)$ berbeda nyata $(\mathrm{P}<0,05)$ lebih rendah, masingmasing: 5,19\% dan 7,27\% dibandingkan dengan kontrol (So).

Probiotik, telah terbukti menjadi alternatif yang paling disukai dan efektif untuk AGP dan inhibitor patogen dalam industri unggas. Saat ini, Lactobacillus, Bacillus, Bifidobacterium, dan Yeast terutama digunakan sebagai persiapan probiotik pada ayam broiler dan ayam petelur (Khan dan Naz, 2013). Diantara mikroba makan langsung ini, anggota Bacillus telah dianggap paling menjanjikan, karena kelangsungan hidup mereka melalui proses pencernaan, perkecambahan dalam saluran pencernaan, dan ekskresi melalui kotoran (Shivaramaiah et al., 2011). Suplementasi probiotik Saccharomyces spp. KB-13 pada level 0,10-0,30\% dalam dalam ransum ayam tidak berpengaruh signifikan terhadap produksi telur. Hal senada dilaporkan oleh Davis dan Anderson (2002) bahwatidak ada peningkatan produksi telur pada ayam petelur yang ditambah dengan bakteri probiotik, termasuk Lactobacillus dan Bacillus. Ini juga sesuai dengan Kalavathy et al. (2009) yang melaporkan bahwa suplementasi probiotik tidak berpengaruh signifikan terhadap produksi telur pada 
Table 2. Pengaruh probiotik Saccharomyces spp. KB-13 (isolasi dari rumen kerbau) terhadap performa produksi telur ayam Lohmann Brown umur 72-80 minggu

\begin{tabular}{|c|c|c|c|c|c|}
\hline \multirow{2}{*}{ Variabel } & \multicolumn{4}{|c|}{ Perlakuan $^{1}$} & \multirow{2}{*}{ SEM $^{2}$} \\
\hline & so & S1 & S2 & S3 & \\
\hline Berat badan awal (g) & $1769.32 a$ & $1772.51 \mathrm{a}$ & $1764.96 a$ & $1780.37 a$ & 22.071 \\
\hline Berat badan akhir (g) & 1786.59a & $1782.63 a$ & $1779.48 a$ & $1790.41 a$ & 25.902 \\
\hline Konsumsi ransum (g/ekor/minggu) & $1084.82 \mathrm{a}$ & $1117.49 a$ & $1078.74 a$ & $1052.58 \mathrm{a}$ & 19.054 \\
\hline Produksi telur (\%) & $78.92 a$ & $80.15 a$ & $81.52 a$ & $81.46 a$ & 1.139 \\
\hline Total berat telur (g/ekor/minggu) & $375.66 b^{3)}$ & $377.86 b$ & $393.17 a$ & $393.45 a$ & 1.672 \\
\hline $\begin{array}{l}\text { Feed conversion ratio (konsumsi } \\
\text { ransum:berat telur) }\end{array}$ & $2.89 a$ & $2.96 a$ & $2.74 b$ & $2.68 b$ & 0.083 \\
\hline
\end{tabular}

Keterangan:

S0):ransum tanpa probiotik sebagai kontrol; S1): ransum dengan 0.10\% Saccharomyces spp.Kb-13; S2): ransum dengan 0.20\% Saccharomyces spp.Kb-13; dan S3): ransum dengan $0.30 \%$ Saccharomyces spp. Kb-13.

SEM: Standard Error of Treatment Means

Nilai dengan huruf yang berbeda pada baris yang sama adalah berbeda nyata $(P<0.05)$

ayam. Produksi telur pada ayam yang diberi kandungan bakteri dan khamir probiotik tidak berbeda secara signifikan dari ayam kontrol yang berusia 40 hingga 52 minggu (Balevi et al., 2001).

Suplemen khamir Saccharomyces spp. KB-13 dalam ransum ayam menghasilkan berat telur yang lebih tinggi, dan rasio konversi pakan (konsumsi pakan: massa telur) yang lebih baik dibandingkan dengan kontrol. Mikroorganisme probiotik, termasuk Lactobacillus, Bacillus, dan Saccharomyces cerevisiae, telah dipelajari sebagai aditif pakan potensial karena mampu memproduksi enzim ekstraseluler yang luar biasa, termasuk protease, amilase, selulase dan lipase (Chen et al., 2009). Enzim ini dapat meningkatkan kecernaan protein, karbohidrat, dan lipid pada ayam pedaging (Salim et al., 2013). Zurmiati et al. (2017) dan Hasan et al. (2016) melaporkan bahwa suplemen Lactobacillus acidophilus secara tunggal atau dalam kombinasi dengan B. subtilis pada setengah dosis dapat meningkatkan jumlah populasi bakteri yang bermanfaat di dalam usus, meningkatkan kecernaan nutrisi, fermentasi dalam cecal, efisiensi pakan, dan kinerja pertumbuhan pada kelinci (Phuoc dan Jamikorn, 2017). Dimasukkannya probiotik ke dalam ransum secara signifikan meningkatkan jumlah sel piala dan panjang villus (Aliakbarpour et al., 2012). Azzam et al. (2011) melaporkan bahwa berbagai faktor, seperti kolonisasi mikroba di usus dapat memengaruhi produksi, sekresi, dan komposisi musin.

Sintesis gen musin yang lebih tinggi setelah pemberian probiotik dapat secara positif mempengaruhi interaksi bakteri dalam saluran pencernaan usus, proliferasi sel mukosa usus dan akibatnya penyerapan nutrisi yang efisien (Aliakbarpour et al., 2012). Menurut Nguyen et al. (2019) peningkatan terbesar dalam kinerja pertumbuhan, kecernaan nutrisi, pencacahan bakteri tinja, dan emisi gas berbahaya pada babi yang disapih diperoleh ketika campuran probiotik ditambah 0,30\%. Hasil serupa diperoleh ketika pakan fermentasi dengan probiotik dalam bentuk kering digunakan sebagai makanan sehari-hari ayam Akar Putra (Lokman et al., 2015). Penelitian yang sama telah dilaporkan oleh Husain et al. (2017); Manafi et al. (2018); dan Sikandar et al. (2017) bahwa efek probiotik adalah peningkatan efisiensi pakan dan kinerja pertumbuhan ayam pedaging.

Suplementasi probiotik Saccharomyces spp. KB13 sebanyak 0,20-0,30\% ke dalam ransum ternyata berpengaruh nyata $(\mathrm{P}<0,05)$ terhadap persentase kulit telur, tebal kulit, warna kuning telur, dan kadar kolesterol kuning telur ayam (Tabel 3). Persentase kulit telur ayam perlakuan S2 dan S3 adalah meningkat secara nyata $(\mathrm{P}<0,05)$ masing-masing: 6,83\% dan 7,99\% lebih tinggi daripada kontrol (So). Terjadi peningkatan yang nyata $(\mathrm{P}<0,05)$ pada persentase kuning telur ayam perlakuan S2 dan S3, masing-masing: 4,73\% dan 4,87\% lebih tinggi daripada kontrol. Sebaliknya, persentase putih telur pada ayam perlakuan S2 dan S3 mengalami penurunan yang nyata $(\mathrm{P}<0,05)$ masing-masing: $3,65 \%$ dan 3,95\% lebih rendah daripada kontrol.

Hasil penelitian menunjukkan bahwa suplementasi probiotik Saccharomyces spp.Kb-13 sebanyak 0,10$0,30 \%$ ke dalam ransum ternyata tidak berpengaruh nyata $(\mathrm{P}>0,05)$ terhadap hough unit (HU), indeks telur, dan berat jenis (BJ) telur dibandingkan dengan kontrol. Tebal kulit telur pada ayam perlakuan S2 dan S3 berbeda nyata $(\mathrm{P}<0,05)$ lebih tebal, masing-masing $10,02 \%$ dan $12,82 \%$ daripada perlakuan So dan S1. Demikian juga halnya dengan warna kuning telur ayam perlakuan S2 dan S3 nyata $(\mathrm{P}<0,05)$ lebih kuning, masing-masing: $17,83 \%$ dan $20,89 \%$ lebih tinggi daripada perlakuan So dan S1. Sebaliknya, rataan kadar kolesterol kuning telur ayam perlakuan $\mathrm{S} 2$ dan $\mathrm{S} 3$ nyata $(\mathrm{P}<0,05)$ lebih rendah, masing-masing: $21,11 \%$ dan $19,22 \%$ daripada kadar kolesterol kuning telur ayam perlakuan So dan S1.

Indeks telur yang tidak berbeda, karena hampir semua perlakuan memiliki asupan pakan yang sama. Mengenai berat telur, ada peningkatan yang signifikan 
Tabel 3. Pengaruh suplementasi probiotik Saccharomyces spp.Kb-13 (isolasi dari cairan rumen kerbau) kualitas external dan kadar kolesterol kuning telur

\begin{tabular}{|c|c|c|c|c|c|}
\hline \multirow{2}{*}{ Variabel } & \multicolumn{4}{|c|}{ Perlakuan ${ }^{1}$} & \multirow{2}{*}{ SEM $^{2}$} \\
\hline & SO & $\mathrm{S} 1$ & $\mathrm{~S} 2$ & S3 & \\
\hline Kulit telur (\% berat telur) & $12.01 b^{3}$ & $12.15 b$ & $12.83 a$ & $12.97 a$ & 0.176 \\
\hline Kuning telur ( $\%$ berat telur) & $28.52 b$ & $28.61 b$ & $29.87 a$ & 29.91a & 0.209 \\
\hline Putih telur (\% berat telur) & $59.47 a$ & $59.24 a$ & $57.30 b$ & $57.12 b$ & 0.492 \\
\hline Haugh unit (tinggi putih:berat telur) & $76.36 a$ & $75.98 a$ & $76.07 a$ & $76.41 a$ & 0.857 \\
\hline Indeks telur (lebar telur:panjang telur) $\times 100 \%$ & $74.81 a$ & $75.38 a$ & $75.05 a$ & $74.97 a$ & 0.803 \\
\hline Berat Jenis (weight : volume) & $1.042 a$ & $1.041 a$ & $1.039 a$ & $1.047 a$ & 0.048 \\
\hline Tebal kulit telur (mm) & $0.429 b$ & $0.437 b$ & $0.472 a$ & $0.484 a$ & 0.013 \\
\hline Warna kuning telur (1-15) & $7.85 b$ & $7.94 b$ & $9.25 a$ & $9.49 a$ & 0.195 \\
\hline Kolesterol kuning telur (mg/g) & $7.39 a$ & $7.41 a$ & $5.83 b$ & $5.97 b$ & 0.304 \\
\hline
\end{tabular}

Keterangan:

SO): ransum tanpa probiotik sebagai kontrol; S1): ransum dengan 0.10\% Saccharomyces spp.Kb-13; S2): ransum dengan 0.20\% Saccharomyces spp.Kb-13; dan S3): ransum dengan $0.30 \%$ Saccharomyces spp. $K b-13$.

SEM: Standard Error of Treatment Means

Nilai dengan huruf yang berbeda pada baris yang sama adalah berbeda nyata $(P<0.05)$

pada ayam yang mendapat 0,20-0,30\% probiotik Saccharomyces spp.Kb-13 dan telah menunjukkan resistensi yang lebih besar terhadap penyakit yang mempengaruhi sistem pencernaan (Prado et al., 2016). Sebaliknya, probiotik makanan tidak berpengaruh signifikan terhadap HU, indeks telur dan BJ telur (Fathi et al., 2018; dan Zurmiati et al., 2017). Hasil yang tidak konsisten dari suplemen probiotik mungkin karena perbedaan jumlah bakteri hidup yang sesuai, umur hewan, dan strain suplementasi (Chen et al., 2017).

Suplementasi probiotik Saccharomyces spp.Kb13pada level 0,20-0,30\% ke dalam ransum ayam petelur secara signifikan meningkatkan karakteristik kualitas telur eksternal (kulit telur, kuning telur, dan ketebalan kulit) ayam petelur. Bidura et al. (2019) melaporkan bahwa suplementasi probiotik Saccharomyces spp ke dalam ransum itik, nyata dapat meningkatkan kualitas fisik telur. Hal ini disebabkan karena adanya kemampuan probiotik dapat meningkatkan penyerapan nutrisi, seperti protein dan mineral. Efek menguntungkan pada ketebalan dan kekuatan kulit telur yang diamati dalam penelitian ini secara langsung terkait dengan pengurangan jumlah telur yang rusak. Peningkatan kualitas telur, karena suplementasi probiotik seperti yang dilaporkan dalam penelitian ini oleh Saleh et al. (2017) bahwa pakan yang dilengkapi dengan probiotik (Aspergillus awamori dan bakteri asam laktat) menunjukkan potensi untuk meningkatkan berat telur, efisiensi pakan, dan kualitas kulit telur selama periode bertelur awal. Hasil signifikan yang serupa dalam berat telur dan kualitas kulit telur juga diperoleh dalam ransum yang diberi probiotik (Sun et al., 2015). Tang et al. (2018) melaporkan bahwa bakteri probiotik menunjukkan efek positif pada produksi telur dan kualitas kulit telur. Efek positif dari suplementasi probiotik pada karakteristik kualitas kulit telur telah dilaporkan (Abdelqader et al., 2013). Swia tkiewicz et al. (2010) mengaitkan efek positif probiotik pada parameter kualitas kulit telur dengan peningkatan ketersediaan usus Ca. Di sisi lain, penambahan probiotik tidak memiliki efek signifikan pada kekerasan cangkang dan ketebalan cangkang (Chen dan Chen, 2003). Mahdavi et al. (2005) dan Mohebbifar et al. (2013) tidak menemukan efek signifikan untuk penggunaan probiotik dalam ransum pada kualitas telur. Fathi et al. (2018) melaporkan bahwa efek menguntungkan yang dihasilkan dari suplementasi probiotik pada kualitas kulit telur diamati tanpa mempengaruhi sifat kualitas telur internal. Dimcho et al. (2005), menemukan bahwa pemberian probiotik tidak mempengaruhi konsentrasi protein total serum ayam.

Sun et al. (2015) melaporkan bahwa suplementasi ransum dengan ragi beras merah dapat meningkatkan kualitas telur ayam petelur tanpa mengganggu kinerja produksi telur. Dilaporkan oleh An et al. (2011) bahwa kadar trigliserida, aspartat aminotransferase, alanine amino transferase, dan glukosa dalam serum berkurang pada kelompok ayam yang mendapat probiotik dibandingkan dengan kelompok kontrol. Hasil serupa telah diamati dengan beberapa jenis probiotik spesifik (Lee et al., 2006; Yin et al., 2010). Saleh et al. (2017) bahwa konsentrasi $\mathrm{Ca}, \mathrm{P}$, dan $\mathrm{Zn}$ dalam kuning meningkat oleh probiotik (Aspergillus awamori dan bakteri asam laktat). Demikian pula dengan hasil yang diperoleh dalam percobaan Mikulski et al. (2012) menemukan bahwa peningkatan retensi Ca pada ayam yang diberi probiotik.

Hasil penelitian menunjukkan bahwa suplementasi probiotik Saccharomyces spp.Kb-13 pada level 0,20$0,30 \%$ dalam ransum berpengaruh signifikan terhadap kadar kolesterol kuning telur ayam. Akan tetapi penelitian Kang et al. (2013) tidak menunjukkan perubahan signifikan dalam profil lipid tikus yang dilengkapi oleh Lactobacillus gasseri, efek hipokolesterolemik 
dari beberapa strain bakteri, termasuk Lactobacillus acidophilus (Park et al., 2008). Tang et al. (2016) melaporkan bahwa ayam petelur yang diberi probiotik secara signifikan menurunkan total asam lemak jenuh kuning telur jika dibandingkan dengan kontrol. Suplementasi probiotik Aspergillus awamori dan bakteri asam laktat memodifikasi profil asam lemak kuning telur dengan meningkatkan asam lemak tak jenuh dan mengurangi asam lemak jenuh (Saleh et al., 2017).

Kadar kolesterol kuning telur secara signifikan lebih rendah pada pemberian ransum yang mengandung khamir Saccharmyces spp.Kb-13 (Grup S2 dan S3). Manipulasi mikroflora enterik dengan probiotik juga dapat memainkan peran penting dalam mengubah metabolisme lipid ayam, karena berbagai penelitian telah menunjukkan bahwa probiotik dapat mengurangi kadar kolesterol dalam kuning telur dan serum (Ezema dan Eze, 2015; Sun et al., 2015; Tang et al., 2016). Menurut Alkhalf et al. (2010), probiotik mengurangi kolesterol dalam darah dengan mendamaikan garam empedu di usus, sehingga mencegah mereka dari bertindak sebagai prekursor dalam sintesis kolesterol. Saccharomyces spp juga ditemukan memiliki aktivitas hidrolitik garam empedu yang tinggi, yang bertanggung jawab untuk dekonjugasi garam empedu (Bidura dan Siti 2017). Menurut Istiqomah et al. (2018) S. cerevisiae berpotensi untuk mengasimilasi kolesterol in vitro. Kolesterol plasma dan trigliserida berkurang pada ayam petelur yang diberi makanan yang dilengkapi dengan probiotik (Fathi et al., 2018). Paryad dan Mahmoudi (2008) juga melaporkan bahwa menambahkan 1,5\% $S$. cerevisiae dalam ransum dapat mengurangi kolesterol serum ayam pedaging. Ada kemungkinan bahwa efikasi probiotik tergantung pada faktor-faktor termasuk komposisi spesies mikroba (campuran tunggal atau multi-strain) dan viabilitas, tingkat suplementasi, metode aplikasi, frekuensi aplikasi, diet keseluruhan, umur burung, kebersihan pertanian keseluruhan, dan tekanan lingkungan faktor (Zhang dan Kim, 2014). An et al. (2008) melaporkan bahwa tidak ada perbedaan yang signifikan dalam aktivitas enzim serum dan konsentrasi berbagai fraksi kolesterol. Hasil yang tidak konsisten dari suplemen probiotik mungkin karena perbedaan jumlah bakteri hidup yang sesuai, umur hewan, dan strain suplementasi (Chen et al., 2017).

\section{SIMPULAN}

Disimpulkan bahwa suplementasi 0,20-0,30\% probiotik Saccharomyces spp. KB-13 dalam ransum dapat meningkatkan massa telur, efisiensi pakan, persentase kuning dan kulit telur, dan ketebalan cangkang, serta penurunan kadar kolesterol dalam kuning telur ayam petelur.

\section{UCAPAN TERIMAKASIH}

Penulis mengucapkan banyak terimakasih kepada Rektor Universitas Udayana, atas ijin dan bantuan dana yang diberikan sehingga penelitian sampai penyusunan paper ini dapat terselesaikan. Kepada Dr. Ni Wayan Siti, MSi dan Andi Udin Saransi, SPt.MPt. atas bantuannya selama penelitian.

\section{DAFTAR PUSTAKA}

Abdelqader, A., Irshaid, R., dan A.R. Al-Fataftah. 2013. Effects of dietary probiotic inclusion on performance, eggshell quality, cecal microflora composition, and tibia traits of laying hens in the late phase of production. Trop. Anim. Health Prod. 45, 1017-1024.

Aliakbarpour, H.R., Chamani, M., Rahimi, G., Sadeghi, A. A. dan D. Qujeq. 2012. The Bacillus subtilis and Lactic Acid Bacteria Probiotics Influences Intestinal Mucin Gene Expression, Histomorphology and Growth Performance in Broilers. Asian-Aust. J. Anim. Sci. 25,1285-1293.

Alkhalf, A., Alhaj, M. \& I. Al-Homidan. 2010. Influence of probiotic supplementation on blood parameters and growth performance in broiler chickens. Saudi J. Biol. Sci. 17, 219-25.

An, B.K., Cho, B.L., You, S. J., Paik, H. D., Chang, H. I., Kim, S. W., Yun, C. W. \& C.W. Kang. 2008. Growth performance and antibody response of broiler chicks fed Yeast derived $\beta$-glucan and single-strain probiotics. Asian-Aust. J. Anim. Sci. 21 (7), 10271032.

An, H.M., S.Y. Park, K. Lee, K.J.R. do, M.K. Cha, S.W. Lee, H.T. Lim \& N.J. Ha, 2011. Antiobesity and lipidlowering effects of Bifidobacterium spp. in high fat diet-induced obese rats. Lipids Health Dis. 10, 116.

Azzam, M. M. M., Zou, X.T., Dong, X.Y. \& P. Xie. 2011. Effect of supplemental L-threonine on mucin 2 gene expression and intestine mucosal immune and digestive enzymes activities of laying hens in environments with high temperature and humidity. Poult. Sci. 90, 2251-2256.

Balevi T, Ucan US, Coskun B, Kurtoglu V, \& I.S.Cetingul. 2001. Effect of dietary probiotic on performance and humoral immune response in layer hens. Br. Poult. Sci. 42, 456-461.

Bai, S.P., Wu, A.M., Ding, X. M., Lei, Y., Bai, J., Zhang, K. Y.\& Chio, J. S. 2013. Effects of probioticsupplemented diets on growth performance and intestinal immune characteristics of broiler chickens. Poult. Sci. 92 (3), 663-670.

Bidura, I G.N.G. and N.W. Siti. 2017. Selection and Implementation of Probiotics Saccharomyces spp. 
Kb-05 and Saccharomyces spp.Kb-08 Isolated from Buffalo Ruments to Increase the Nutritional Value of Rice Bran. J. Biol. Chem. Research. Vol. 34 (2), 866-877

Bidura, I G.N.G., Candrawati, D.P.M.A. and D. A. Warmadewi. 2015. Selection of Khamir Saccharomyces spp. Isolated from Colon of Native Chickens as a Probiotics Properties and has CMCase Activity. J. Biol. Chem. Research. Vol. 32, (2), 683-699

Bidura, I G.N.G., Candrawati, D.P.M.A. and I.B.G. Partama. 2014. Selection of Saccharomyces spp isolates (isolation from colon beef of Bali cattle) as probiotics agent and colon cancer prevention and its effect on pollard quality as feed. Journal of Biological and Chemical Research Vol. 31 (2), 1043-1047

Bidura, I G.N.G., N.W. Siti and I.B.G. Partama. 2019. Effect of probiotics, Saccharomyces spp.Kb-5 and $\mathrm{Kb}-8$, in diets on growth performance and cholesterol levels in ducks. South African Journal of Animal Science Vol. 49 No. 2: 219-226. http:// dx.doi.org/10.4314/sajas.v49i2.2

Bidura,I G.N.G., Partama, I.B.G., Putra, D.K.H. and U. Santoso. 2016. Implementation on diet of probiotic Saccharomyces spp.SB-6 isolated from colon of Bali cattle on egg production and egg cholesterol concentration of Lohmann brown laying hens. Int. J. Curr. Microbiol. App. Sci. Volume 32 (2), 683-699

Bidura, I G.N.G., N.W. Siti and I.B.G. 2019. Partama Effect of probiotics, Saccharomyces spp.Kb-5 and $\mathrm{Kb}-8$, in diets on growth performance and cholesterol levels in ducks. South African Journal of Animal Science Vol. 49 (2), 219-226

Bidura, I G.N.G., Suyadnya, I.P., Mahardika, I.G., Partama, I.B.G., I G.L. Oka, and I G.A.I. Aryani. 2012. The implementation of Saccharomyces spp.n-2 isolate culture (isolation from traditional yeast culture) for improving feed quality and performance of male Bali duckling. Agricultural Science Research Journal Vol. 2 (9), 486-492

Candrawati, D.P.M.A., Warmadewi, D.A. and I G.N.G. Bidura. 2014. Isolation of Saccharomyces spp from Manure of Beef Bali cattle as a probiotics properties and has CMC-ase activity to improve nutrient quality of rice bran. Journal of Biological and Chemical Research Vol. 31 (1), 39-52

Chen, Y.C. and T.C. Chen. 2003. Effects of commercial probiotic or prebiotic supplementation on production, size and quality of hen's egg. Poult. Sci. 82 (Suppl. 1), 330. Abstract.

Chen, C.Y., Chen, S.W. and H. T. Wang. 2017. Effect of supplementation of yeast with bacteriocin and Lactobacillus culture on growth performance, cecal fermentation, microbiota composition, and blood characteristics in broiler chickens. Asian-Australas J Anim Sci Vol. 30 (2), 211-220

Chen, K.L., Kho, W.L., You, S.H., Yeh, R.H., Tang, S.W. and C.W. Hsieh. 2009. Effects of Bacillus subtilis var. natto and Saccharomyces cerevisiae mixed fermented feed on the enhanced growth performance of broilers. Poult. Sci. 88, 309-315.

Cully, M. 2014. Public health: the politics of antibiotics. Nature. 509, S16-S17.

Davis, G.S. and K.E. Anderson. 2002. The effects of feeding the direct-fed microbial, primalac, on growth parameters and egg production in single comb white leghorn hens. Poult. Sci. 81, 755-759.

Dimcho D, Boicheva S, Simeonova T, and T. Vlaikova. 2005. Effect of feeding Lactina probiotic on performance, some blood parameters and caecal microflora of mule ducklings. Trakia J. Sci. 3, 22-28.

Ezema, C. and D. C. Eze. 2015. Probiotic Effect of Yeast (Saccharomyces cerevisiae) on Hen-Day Egg Performance, Serum and Egg Cholesterol Levels in Laying Chicken. Pakistan Journal of Nutrition 14 (1), 44-46

Fathi, M., Ibrahim Al-Homidan, Abdelaziz Al-Dokhail, Tarek Ebeid, Osama Abou-Emera \& A. Alsagan. 2018. Effects of dietary probiotic (Bacillus subtilis) supplementation on productive performance, immune response and egg quality characteristics in laying hens under high ambient temperature, Italian Journal of Animal Science, 17, 3, 804-814, DOI: 10.1080/1828051X.2018.1425104

Hasan, S.A.J., Lokman, I.H., Naji, S.A., Zuki, A.B.Z. and A.B. Kassim, 2016. Effects of dietary supplementation of wet fermented feed with probiotic on the production performance of Akar Putra chicken. Asian J. Poult. Sci. 10, 72-77

Husain, D.R., Dwyana, Z., Ambeng, Anggraeni, A. and Sulfahri. 2017. Evaluation of bacteria from Gallus domesticus as a potential probiotic in broiler chicks: Effects on growth performance and feed conversion ratio. Int. J. Poult. Sci. 16, 43-49.

Istiqomah,L., M. Anwar, A.S. Anggraeni \& E. Damayanti. 2018. Cholesterol Assimilation of Saccharomyces cerevisiae B-18 isolated from gastrointestinal tract of Javanese duck. J. Indonesian Trop. Anim. Agric. 43 (2), 149-158

Kalavathy R, Abdullah, N. and S. Jalaludin. 2003. Effects of Lactobacillus cultures on growth performance, abdominal fat deposition, serum lipids and weight of organs of broiler chickens. Br. Poult. Sci. 44, 139-44

Kalavathy, R., Abdullah N, Jalaludin S, Wong M, and Y.W. Ho. 2009. Effects of Lactobacillus cultures on performance of laying hens, and total cholesterol, lipid and fatty acid composition of egg yolk. J. Sci. 
Food Agric. 89, 482-486.

Kang, Ji-Hee, Yun, Sung-Il, Park, Mi-Hee, Park, JunHong, Jeong, So-Young and Park Han-Oh. 2013. Anti-obesity effect of Lactobacillus gasseri BNR17 in high-sucrose diet-induced obese mice. PloS One, 8, e54617.

Khan, R.U. and S. Naz. 2013. Application of probiotics in poultry production. World's Poultry Science Journal, 69, 621-632.

Khan, R.U., S. Naz, K. Dhama, K. Kathrik, R. Tiwari, M.M. Abdelrahman, I.A. Alhidary \& A. Zahoor. 2016. Direct-fed microbial: Beneficial applications, modes of action and prospects as a safe tool for enhancing ruminant production and safeguarding health. International Journal of Pharmacology, 12 (3), 220-231.

Lei, K., Li, Y.L., Yu, D.Y., Rajput, I.R., and Li, W.F. 2013. Influence of dietary inclusion of Bacillus licheniformis on laying performance, egg quality, antioxidant enzyme activities, and intestinal barrier function of laying hens. Poultry Sci. 92, 2389-2395.

Lee, H.Y., J.H. Park, S.H. Seok, M.W. Baek, D.J. Kim, K.E. Lee and J.H. Park. 2006. Human originated bacteria, Lactobacillus rhamnosus PL60, produce conjugated linoleic acid and show anti-obesity effects in diet-induced obese mice. Biochim. Et Biophy. Acta (BBA)-Mol. Cell Biol. Lipids, 1761, 736-744.

Li L, Xu CL, Ju C, Ma Q, Hao K, Jin ZY, and Li K. 2006. Effects of a dried Bacillus subtilis culture on egg quality. Poult. Sci. 85, 364-368.

Lokman, I.H., Jawad, S.H., Zuki, A.B.Z. and A.B. Kassim. 2015. Effect of dry probiotic supplemented fermented feed on production performance of akar putra chicken. Int. J. Poult. Sci.14, 420-426.

Mahdavi AH, Rahmani HR, and Pourreza J. 2005. Effect of probiotic supplements on egg quality and laying hens performance. Int. J. Poult. Sci. 4, 488-492.

Manafi, M., Hedayati, M. and S. Mirzaie. 2018. Probiotic Bacillus species and Saccharomyces boulardii improve performance, gut histology and immunity in broiler chickens. South African Journal of Animal Science, 48 (2), 379-389

Mikulski D, Jankowski J, Naczmanski J, Mikulska M, and Demey, V. 2012. Effects of dietary probiotic (Pediococcus acidilactici) supplementation on performance, nutrient digestibility, egg traits, egg yolk cholesterol, and fatty acid profile in laying hens. Poult Sci. 91, 2691-2700.

Mohebbifar A, Kashani H, Afsari M, and Torki M. 2013. Effects of commercial prebiotics and probiotics on performance of laying hens, egg traits and some blood parameters. Annu Rev. Res. Biol. 3, 921-934. Mujnisa, A., Lailya Gustina, Asmuddin Natsir and
Syamsuddin Hasan 2018. Dosage effects of Lactococcus lactis ssp. lactis 2 as a probiotic on the percentage of carcass, abdominal fat content and cholesterol level in broilers. Int. J. Poult. Sci., 17: 100-105

Nguyen, D.H., C. M. Nyachoti and I. H. Kim. 2019. Evaluation of effect of probiotics mixture supplementation on growth performance, nutrient digestibility, faecal bacterial enumeration, and noxious gas emission in weaning pigs, Italian Journal of Animal Science, 18:1, 466-473, DOI: 10.1080/1828051X.2018.1537726

Oyugi, D. A., Ayorinde, F.O., Gugssa, A., Allen, A. Izevbigie, E.B., Eribo, B. and Anderson, W.A. 2011. Biological Activity and Mass Spectometric Analysis of vernonia-amygdalina Fractions, J. Biosci. Technol. 2 (3), 287-304.

Park, Y.H., J.G. Kim, Y.W. Shin, H.S. Kim, Y.J. Kim, T. Chun and K.Y. Whang. 2008. Effects of Lactobacillus acidophilus 43121 and a mixture of Lactobacillus casei and Bifidobacterium longum on the serum cholesterol level and fecal sterol excretion in hypercholesterolemia-induced pigs. Biosc. Biotechnol. Biochem., 72, 595-600.

Paryad, A., and Mahmoudi, M. 2008. Effect of different levels of supplemental yeast (Saccharomyces cerevisiae) on performance, blood constituents and carcass characteristics of broiler chicks. Afri. J. Agri. Res. 3, 835-842.

Phuoc, T.L. and U. Jamikorn. 2017. Effects of probiotic supplement (Bacillus subtilis and Lactobacillus acidophilus) on feed efficiency, growth performance, and microbial population of weaning rabbits. AsianAustralas J Anim Sci 30, 198-205

Prado, M.R.M., S.G. Franco and C.R. Soccol. 2016. Development of a Fermentation Medium for Production of Probiotics and their Use in Feed for Laying Hens. Int. J. Curr. Microbiol. App. Sci. 5 (6), 357-369

Puspani, E., Candrawati, D.P.M.A. and I.G.N.G. Bidura. 2016. Implementation of probiotics cellulolitic B-7 bacteria (isolation from buffalo rumen) into ration on the performance, abdominal fat and serum cholesterol of duck. Int. J. Curr. Microbiol. App. Sci. Vol. 5 (11), 432-441

Ristiani, N. M., Bidura, I.G.N.G. and D.A. Warmadewi. 2017. The Effect of Saccharomyces spp.Gb-9 (Isolated from Colon of Native Chicken) on the Growth Performance and Meat Cholesterol Level in Broilers. J. Biol. Chem. Research Vol. 34 (1), 118-128

Saleh, A.A., B. Gálik, H. Arpášová, M. Capcarová, A. Kalafová, M. Šimko, M. Juráček, M. Rolinec, D. Bíro and A. M. Abudabos. 2017. Synergistic effect of feeding Aspergillus awamori and lactic 
acid bacteria on performance, egg traits, egg yolk cholesterol and fatty acid profile in laying hens. Italian Journal of Animal Science, 16:1, 132-139, DOI: $10.1080 / 1828051 X .2016 .1269300$

Salim, H.M., Kang, H.K, Akter, N., Kim D.W., Kim J.H., Kim M., Na J.C., Jong H.B., Choi H.C., and Suh, O.S. 2013. Supplementation of direct-fed microbials as an alternative to antibiotic on growth performance, immune response, cecal microbial population, and ileal morphology of broiler chickens. Poult. Sci. 92, 2084-2090.

Scott, M. L., M. C. Neisheim, M.C. and R. J. Young. 1982. Nutrition of The Chickens. 2nd Ed. Publishing by : M. L. Scott and Assoc. Ithaca, New York.

Shivaramaiah S, Pumford NR, Morgan MJ, Wolfenden RE, Wolfenden AD, Torres-Rodr iguez A, Hargis BM, and Tellez G. 2011. Evaluation of Bacillus species as potential candidates for direct-fed microbials in commercial poultry. Poult. Sci. 90, 1574-1580.

Sikandar, A., Zaneb, H., Younus, M., Masood, S., Aslam, A., M. Shah \& H. Rehman. 2017. Growth performance, immune status and organ morphometry in broilers fed Bacillus subtilis-supplemented diet. South African Journal of Animal Science Vol 47 (3), 378388

Siti, N.W., Candrawati, D.P.M.A., Warmadewi, D.A. and I.G.N.G. Bidura. 2014. Isolation of Saccharomyces $s p p$ from Manure of Beef Bali cattle as a probiotics properties and has $\mathrm{CMC}$-ase activity to improve nutrient quality of rice bran. Journal of Biological and Chemical Research Vol. 31 (1), 39-52

Sobczak, A. and Kozłowski, K. 2015. The effect of a probiotic preparation containing Bacillus subtilis ATCC PTA-6737 on egg production and physiological parameters of laying hens. Ann. Anim. Sci. 15, 711723.
Sun, H., Yifei Wu, Xin Wang, Yong Liu, Xiaohong Yao and Jiangwu Tang. 2015. Effects of Dietary Supplementation with Red Yeast Rice on Laying Performance, Egg Quality and Serum Traits of Laying Hens. Italian Journal of Animal Science, 14:3, 4059, DOI: 10.4081/ijas.2015.4059

Swia , tkiewicz, S., Koreleski, J., and Arczewska, A. 2010. Laying performance and eggshell quality in laying hens fed diets supplemented with prebiotics and organic acids. Czech. J. Anim. Sci. 55, 294-306.

Tang, R.Y., Zhou Lin Wu, Guo Ze Wang and Wen Chao Liu. 2018. The effect of Bacillusamyloliquefaciens on productive performance of laying hens. Italian Journal of Animal Science, 17: 2, 436-441

Tang, C., P.C.X. Hoo, L.T.H. Tan, P. Pusparajah \& T.M. Khan. 2016. Golden needle mushroom: A culinary medicine with evidenced-based biological activities and health promoting properties. Front. Pharmacol., Vol. 7. 10.3389/fphar.2016.00474.

Tufarelli, V., A. M. Crovace, G. Rossi and V. Laudadio. 2017. Effect of a dietary probiotic blend on performance, blood characteristics, meat quality and faecal microbial shedding in growing-finishing pigs. South African Journal of Animal Science, 47 (6): 875-882

Yin, Y.N., Q.F. Yu, N. Fu, X.W. Liu and F.G. Lu. 2010. Effects of four Bifidobacteria on obesity in high-fat diet induced rats. World J. Gastroenterology: WJG, 16, 3394-3394.

Zhang Z.F. and Kim, I.H. 2014. Effects of multistrain probiotics on growth performance, apparent ileal nutrient digestibility, blood characteristics, cecal microbial shedding, and excreta odor contents in broilers. Poult. Sci. 93, 364-70.

Zurmiati, Wizna, M.H. Abbas, M.E. Mahata and R. Fauzano, 2017. Effect of Bacillus amyloliquefaciens as a probiotic on growth performance parameters of Pitalah ducks. Int. J. Poult. Sci., 16, 147-153. 